\title{
Parents, Schools and Financial Crisis in Contemporary Greece
}

\author{
Dr Dimitris T. Zachos \\ Assistant Professor of Pedagogy - Intercultural Education \\ Aristotle University of Thessaloniki \\ Fuculty of Education, School of Primary Education \\ Tel: 30-23-1099-1252 E-mail: dimzachos@eled.auth.gr
}

Ioanna Papapostolou

E-mail: Joanna.pap7@windowslive.com

Received: August 21, 2016 Accepted: Sep. 13, 2016 Published: November 1, 2016

doi:10.5296/jse.v6i4.9965 URL: http://dx.doi.org/10.5296/jse.v6i4.9965

\begin{abstract}
The purpose of this grounded theory study is to draw on the experiences and views of primary school board members of Parents and Guardians Associations of Thessaloniki's and to explore the ways they deal with issues occurred after financial crisis in Greece began. Three research questions related to the aims of our study were posed: First, what are the research participants' incentives for becoming board members of Association of Parents \& Guardians? Second, how these institutions work under current circumstances and what are the ultimate goals? Third, what are the attitudes and practices of the individuals who took part in our research towards issues of social justice in education? Data were collected through twenty semi-structured interviews and analyzed through Grounded Theory design. As our data suggests, board members of Associations of Parents \& Guardians regard social justice issues as important; they appear to be active in taking steps and implementing measures aimed at empowering students in need; they allocate financial resources to low-income pupils and have deep faith of equity in education.
\end{abstract}

Keywords: Parents and Guardians Association; social justice; financial crisis; primary schools; 


\section{Introduction}

For the last six years, Greek society has gone through a period of an extended crisis, the ramifications of which are apparent in all areas of financial, political and social life. The policies imposed by Greece's lenders mainly weigh in favor of the debt and of the neoliberal doctrines. Despite six years having passed, the financial recession remains a reality. As a consequence, the population's standard of living is constantly diminishing, while at the same time the unemployment rate, the numbers of semi-employed and poorly paid people (e.g., people on low wages or who suffer delays in payments) are rising. All of these factors lead to job-related insecurity for the majority working community.

The privatization of enterprises and organizations currently under state control is the principal aim of the suggested policies. Education is one of the institutions whose largest part remains under state control. The plan for the gradual privatization of educational services is being brought to fruition in two separate ways: Firstly, through institutional granting of functions, responsibilities and rights which up until recently used to be held exclusively by the public sector (e.g., the recognition of qualifications issued by not-state universities). It should be highlighted that this attempt towards even more extensive privatization of education is against Article $16 \S 4$ of the Greek Constitution, which clearly states that: "All Greek citizens have the right to free education, throughout all its levels at public schooling institutions" (Hellenic Parliament, 2008: 30). Secondly, privatization of education is gaining prominence by means of insufficient subsidizing, which is inextricably linked to schools' poor function or its degrading malfunction. As a result, people keen to attend such institutions are indirectly forced to pay for educational services which were previously freely available; a case in point being the Master Programs provided by state funded universities.

With regards to primary education, which is what our research has exclusively focused on, poor funding has severely diminished both the function of schools and the community members' lives. More analytically, schools reporting inadequate specialist staff from the very first months of the academic year has become the rule rather than the exception. In some cases, schools being short of their required number of teachers is prolonged even until the Christmas holiday period. Furthermore, some additional issues intimately connected to the purposes of this paper are: First, rumours circulating in the summer of 2015 about the suspension of "oloimera" ["all-day" schools] (Lakasas, 2015); "oloimera" consist of a unit of state schools, which start earlier and finish later than the mainstream schools. Although the aforementioned rumors appeared false, legislation concerning enrollment to "oloimera" became stricter and, as a result, a number of pupils coming from families that one of the parents was unemployed, were excluded from "oloimera". Furthermore, from now on, schools schedule has shrunk, meaning that daily operation finishes at $1.15 \mathrm{pm}$ instead of $2 \mathrm{pm}$ which was the case in the past. A second issue arisesfrom severe delays in the "oloimera" schools staffing that was reported until late October 2015 (Anonymous, 2015). Third, thelack of psychologists and social workers, who provide their services both to pupils and their parents and guardians. Fourth, the total absence of students' means of commuting (school buses) was a major inconvenience for the first two months (September, October) of the last five academic years due to payment delays. Last but not least, an array of compensatory 
education structures has grown weaker (Reception and Tutorial classes for foreign students, Parallel Support program for students with special educational needs, etc.).

Education's defunding has reached the point where a large number of schools cannot afford the basic expenses with which they function, such as electricity, gas / petrol and water bills, along with their premises related repairs, maintenance and miscellaneous consumables (e.g., replacement parts for any kind of devices, paper sheets, pencils, envelopes, etc.). Pupils' parents and guardians are either called by schools' headmasters or are de facto forced to contribute financially for essentials (such as stationery and copy paper) or for basic maintenance (repairs of school premises, to cover heating bills, etc.) and other school expenses. It is worth mentioning that the coverage of school costs with funds deriving solely from the state budget was regarded as a taboo issue in Greece.

\subsection{The role of parents and guardians in the school community}

Educators', parents' and guardians' ideological perspectives, local community residents' living conditions and cultural capital as well as the unique climate of every school unit appear to be factors in determining the extent of social justice implementation in schools. The capabilities of parents and guardians serving on the school governing body are of their own significance (Joubert \& Van Rooyen, 2014: 20). Participation of parents and guardians in the administrative boards of Associations of Parents and Guardians (hereinafter ASP\&G), seems to be low (Deem, Brehony \& Hemmings, 1992: 220, Mylonakoy-Keke, 2006). Such poor parent participation results in headmasters taking active role in order for the objectives to be achieved and the association to be established. According to informal discussions we had with the twenty headmasters of the schools that were included in our research, in many cases they (headmasters) resorted to interfering themselves to ASP\&G agenda, due to parents' anaemic participation.

Historical and social conditions shape the essence of the relations between schools and their pupils' parents and guardians. In Greece, once the seven-year (1967-1974) dictatorship was disestablished and in the years that followed, the notions of democracy and of all students' equal participation to all educational levels, prevailed ideologically. It is characteristic that after the late 1980 's, education was regarded to be a social necessity by the whole spectrum of political parties (conservatives, progressives and radicals) (Kyprianos, 2004). During that period, nine-year compulsory education was officially established by law, compensatory education was both established and solidified and the number of students admitted to universities increased.

The democratization of educational mechanisms was legislatively reflected in 1985 (Law No. 1566), radically changing the way education functioned until then. A set of measures aiming to abolish the autocratic framework was introduced in primary and secondary schools: The delegation of decision-making to a collective agency (Teachers Association) and the establishment of "popular participation" (local authorities, local community, parents and guardians) in the organizational bodies were set up in every school. Under the jurisdiction of the aforementioned new law, an Association of School Parents and Guardians should be established in every school (Law 1566/85, Art. 53). ASP\&G would have a delegate on both 
the School Committee (Law 1566/85, Art. 52), which until recently administered school financial issues management, as well as on the school board. The aim of the school board is to "ensure the normal function of the school, the proper hygiene both of the pupils and the school environment... and the mutual communication between teachers and pupils' families" (Law 1566/85, Art. 51). The ASP\&G administrative board of each school consists of five members whose service lasts two years. ASP\&G representatives from the same municipal district, municipality, prefecture, county and, finally, state formed their higher Unions. However, school teachers resisted such parent and guardian' involvement in school management thereby resulting in the ASP\&G board members' being restricted to organizing celebratory events such as dancing nights, gift sharing, etc. (Riga \& Souliara, 2016). It should be noted here that ASP\&Gs in Greece are associations exclusively composed of parents as opposed to Parent Teachers Associations (PTAs) formal organisations operating in the United States and the United Kingdom; the latter are not only composed of parents, but of teachers and staff as well, all of whom in turn unitedly aim to facilitate parental participation in schools.

School parents' and guardians' participation in school Management Bodies is an issue closely related to factors such as gender, occupation, financial, social and educational background. Parents and guardians coming from higher socioeconomic backgrounds are more actively involved in the administrative boards of ASP\&Gs (Griffith, 2014: 73; Epstein, 1995: 703). Members of those socioeconomic groups feel more comfortable within the school environment, since they have common targets, use the same "language" and deploy the knowledge set provided by the education they received (Manesis, 2008: 176). On the other hand, families from lower socioeconomic classes are not -compared with individuals from higher economic status- equally represented in the school boards and the school management. This might be due to hesitation, lack of self-confidence or increased family-related responsibilities and thus limited free time (Chikoko, 2008: 254; Coleman \& Churchill, 1997: 3; Deem, Brehony \& Hemmings, 1992: 219; Hoover-Dempsey \& Sandler, 1997: 7; Pomerantz, Moorman \&Litwack, 2007: 375). When teachers appeal for collaboration with parents, middle class parents usually respond positively. In some cases, middle class parents themselves take initiatives to communicate with teachers in order to resolve academic issues, participate in school life and cooperate with school. As it concerns working-class parents, it seems that they are more reluctant to participate in school life and their communication with their pupils' teachers is limited to practical, non-academic issues (Lareau, 1987: 78).

With regards to the academic background of the parents and guardians participating in the school boards, the highest portion areuniversity degree holders from middle classes (Chan \& Chui, 1997: 104; Pomerantz, Moorman \& Litwack, 2007: 375; Mncube, 2009: 95). This is because, according to Kladakis (2012: 406), they have had unobstructed school experiences.

As it concerns gender as a parameter influencing parents' participation, it seems that women participate more actively compared to their husbands. Mothers supervise their offspring's education more intimately, "a pattern that appears to be related to traditional beliefs about gender roles, sociocultural prescriptions and gender-linked patterns of power distribution in society" (Hoover-Dempsey \& Sandler, 1997: 6). However, women involved in the school 
decision-making process are overshadowed by their male counterparts quite regularly (Mncube, 2009: 94).

Some additional reasons that seem to determine the intensity of parents' and guardians' involvement in school life are: Their relevant experience; the level of satisfaction from school's operation; the importance they appoint to their children' education (Chan \& Chui, 1997: 103) and their desire to influence their child's experience positively (Deem, Brehony \& Hemmings, 1992: 220).

It should be noted here that in Greece, institutional framework established by Law No. $1566 \backslash 1985$ was never renewed. The aforementioned Law, which signaled the termination of an era where parents were scarcely informed and had nearly no right to interfere in school life (Kladakis, 2012: 55), was never adapted to the contemporary demands and data. As a consequence, parents' engagement in school life still remains rather limited, without meaningful management responsibilities. In addition, teachers and schoolmasters treat parents instrumentally (Shun, 2012: 10), meaning they never ask for ASP\&G support or contribution (Antonopoulou, Koutrouba \& Babalis, 2010: 337). Teachers prefer parents to be mere "observers" and recipients of their decisions (Kladakis, 2012: 23). As a consequence, teachers marginalize parents' and guardians' participation to school life (Chikoko, 2008: 257; Shun: 2012: 2).

A plea for the increase in parental involvement in decision-making regarding their children' education is one of the main arguments underpinning the promotion of an array of school reforms (school choice movement) that are currently being promoted by international organizations such as the OECD (2011: 34). Further parental involvement seems to have gained ground in Greece as well (Zachos, 2007).

\subsection{Parents and social justice in education}

Social justice is an umbrella term with multiple meanings (Furman, 2012: 193), which many scholars, politicians and journalists use according to their ideological and political views. We advocate an approach according to which social justice implies a just share of wealth; society is responsible to protect human dignity and provide equal consideration to all people according to their needs, talents, and choices (Young, 1990). Therefore, actions in favor of social justice should be oriented towards people living in the margins of society (Bogdan \& Biklen, 1988: 21). In our opinion, whoever makes use of the term "social justice" acknowledges the existence of social inequalities and advocates their eradication.The appeasement of social inequalities is supported by those believing that all individuals must have exuberant educational experiences, which in turn will assure that they can achieve best outcomes.

Social justice and democratic community have become urgent concerns for educational scholars and practitioners (Furman \& Shields, 2005: 119). The incorporation of social justice elements in education aims to manage / reduce / resolve disputes among various social groups, without which any intervention is doomed to fail (Tapper, 2013: 412). 
Within this framework, the first step towards social justice in education is the unconditional inclusion of all students at schools, regardless of their gender, race, social class, special educational needs or sexual orientation. The inclusion of students with learning difficulties within the mainstream classrooms, along with the enhancement of marginalized students' school performance is a second step (Theoharis, 2007: 236). Other steps include granting opportunities to all students in order to access high quality education (Deem, Brehony \& Hemmings, 1992: 210) and not just conventionally attend school without gaining any substantial benefits from it. Furthermore, schools need to be adequately resourced so that they can provide opportunities for students to access a good education (Zachos \& Matziouri, 2015)and consider organising open discussions on topics such as racism, racial discriminations and commit to equal opportunities in education (Theoharis, 2007: 236).

\section{Method}

\subsection{Research design}

Through grounded theory (hereinafter GT), one of the five traditions of qualitative research (Creswell, 1998), we sought to explore the way ASP\&G administrative boards function, participating members' incentives as well as their attitudes towards issues of social justice in education. Our emphasis on social justice issues has been an additional reason for choosing GT, given that this research method is "recommendable in social justice inquiries, since applying it broadens and sharpens the scope of the inquiry" (Charmaz, 2005: 507-508).

Grounded Theory method provides a qualitative way of developing theory (Strauss \& Corbin, 2008). Grounded theorists are simultaneously engaging in data collection and analysis, which may lead them to the readjustment and enrichment of their initial research questions. Additionally, through systematic data processing, the researcher discovers new concepts, whose formulation and interconnection create (or enrich) theory. It is worth noting that the methodology is regarded as a "practical activity of engaging the world and of constructing abstract understandings about and within it" (Charmaz, 2006: 128).

GT that aims to create and interrelate new concepts is better accomplished when the researcher collects and analyses data without theory (literature review). However, the previous knowledge was taken into account and a more reflective approach, where a literature review can assist the researchers' effort to find gaps in knowledge on the topic (Stern, 1980), was followed in our study. The conducted literature review revealed that, even though a plethora of research and theoretical studies on parental involvement was detected, there aren't many concerning the parents' and guardians' views. Additionally, the aforementioned review provided a legitimization for our study and led us to a better covering of the issues at stake.

\subsection{Research questions}

Our research aimed to cover topics and answer relevant questions that have not been adequately addressed (or not addressed at all) by other scholars' studies. Our central research foci were three: 


\section{Ml Macrothink}

First, the identification of the profile and motivations of parents who despite experiencing the effects of the prolonged recession (unemployment, underemployment, insecurity in employment), devoted their free time to participate in the administrative boards of ASP\&Gs.

Second, the identification of ASP\&G core goals and the framework of its function (time spent, relations with the school and the teachers, connections with local communities, monetary plans), given that Greeks seem to have lost their faith in the effectiveness of collective actions.

Third, the discovery of ASP\&G board members' attitudes and practices regarding social justice issues in the educational setting.

\subsection{Setting and participants}

The research was conducted between September - December 2015 in Thessaloniki, Greece's second major economic, industrial, commercial and political center,and a major transportation hub for the rest of south-eastern Europe. Three pilot interviews preceded the implementation of the main research. Participants were selected in order to serve the purposes of our study; we identified twenty ASP\&G board members whose children were attending schools with high (more than $25 \%$ of the total population) proportions of ethnically / nationally / culturally diverse pupils. The twenty interviewees represented fifteen different schools of Thessaloniki; these schools were located in areas where people deal with harsher financial and social problems (unemployment, hunger, delinquency). Eligible participants, in terms that they serve as ASP \&G board members in schools with a high proportion of diverse pupils, were selected upon their willingness to take part in the research. Researchers obtained ethical approval before conducting the interviews from local educational authorities and the headmasters of the schools.

Half of these participants were ASP\&G board members of public schools locatedin eastern Thessaloniki, whereas the other half were from western Thessaloniki. All twenty participants were Greeks with ages ranging from 34-50. Eighteen of them were women and the remaining two were men. At this point, we believe that it is essential to emphasise that the latter (male participants) were both presidents of the ASP\&G administrative board, occupying the highest position in hierarchy.

Regarding their educational background, most participants were tertiary education (university, technical training institutes) graduates. Finally, as it concerns their occupations, the majority of our participants were self-employed and a considerable number of women were unemployed (More analytically see Table 1). 
Table 1. Participants' demographic data

\begin{tabular}{|c|c|c|c|c|c|}
\hline GENDER & AGE & ASP\&G POSITION & $\begin{array}{l}\text { YEARS OF } \\
\text { ATTENDANCE }\end{array}$ & OCCUPATION & EDUCATION \\
\hline FEMALE & 40 & TREASURER & 1 & UNEMPLOYED & TERTIARY \\
\hline FEMALE & 53 & CHAIR & 4 & RETIRED & $\begin{array}{l}\text { MASTER } \\
\text { DEGREE }\end{array}$ \\
\hline FEMALE & 34 & $\begin{array}{l}\text { COMMITTEE } \\
\text { MEMBER }\end{array}$ & 1 & UNEMPLOYED & TERTIARY \\
\hline MALE & 50 & CHAIR & 3 & SELF EMPLOYED & $\begin{array}{l}\text { MASTER } \\
\text { DEGREE }\end{array}$ \\
\hline FEMALE & 35 & $\begin{array}{l}\text { COMMITTEE } \\
\text { MEMBER }\end{array}$ & 1 & PRIVATE EMPLOYEE & TERTIARY \\
\hline FEMALE & 40 & CHAIR & 3 & RETIRED & TERTIARY \\
\hline FEMALE & 40 & CHAIR & 1 & PRIVATE EMPLOYEE & TERTIARY \\
\hline FEMALE & 38 & CHAIR & 3 & SELF EMPLOYED & SECONDARY \\
\hline MALE & 45 & CHAIR & 1 & SELF EMPLOYED & TERTIARY \\
\hline FEMALE & 45 & $\begin{array}{l}\text { COMMITTEE } \\
\text { MEMBER }\end{array}$ & 1 & SELF EMPLOYED & $\begin{array}{l}\text { MASTER } \\
\text { DEGREE }\end{array}$ \\
\hline FEMALE & 50 & $\begin{array}{l}\text { COMMITTEE } \\
\text { MEMBER }\end{array}$ & 1 & RETIRED & TERTIARY \\
\hline FEMALE & 50 & CHAIR & 5 & SELF EMPLOYED & TERTIARY \\
\hline FEMALE & 35 & $\begin{array}{l}\text { COMMITTEE } \\
\text { MEMBER }\end{array}$ & 1 & SELF EMPLOYED & SECONDARY \\
\hline FEMALE & 48 & TREASURER & 4 & $\begin{array}{l}\text { GOVERNMENT } \\
\text { EMPLOYEE }\end{array}$ & TERTIARY \\
\hline FEMALE & 40 & CHAIR & 2 & SELF EMPLOYED & SECONDARY \\
\hline FEMALE & 35 & CHAIR & 1 & SELF EMPLOYED & TERTIARY \\
\hline FEMALE & 45 & TREASURER & 1 & PRIVATE EMPLOYEE & TERTIARY \\
\hline FEMALE & 45 & $\begin{array}{l}\text { COMMITTEE } \\
\text { MEMBER }\end{array}$ & 2 & UNEMPLOYED & TERTIARY \\
\hline FEMALE & 35 & $\begin{array}{l}\text { COMMITTEE } \\
\text { MEMBER }\end{array}$ & 2 & PRIVATE EMPLOYEE & SECONDARY \\
\hline FEMALE & 35 & $\begin{array}{l}\text { COMMITTEE } \\
\text { MEMBER }\end{array}$ & 2 & UNEMPLOYED & SECONDARY \\
\hline
\end{tabular}




\subsection{Data collection \& analysis}

We used a semi-structured interview technique in order to collect our data and develop grounded theory. Semi-structured interviews are loosely-structured, open-ended interviews, based on a restricted number of predetermined questions. Respondents have the opportunity to express their experiences, views and approaches freely and researchers are able to form new questions and themes whilst conducting the interview.

As we have already mentioned, we were originally planning to ask participants twenty - nine questions. The first ten were related to demographic data (age, gender, school setting, educational background, socioeconomic status, years of attendance on ASP\&G, number and age of participant's children attending the school). The rest were related to our research questions. Noting saying that the predetermined order of the questions was not always followed; we grasped every opportunity arose in order to pose new questions and develop new themes in our study.

From the twenty semi-structured interviews conducted with ASP\&G board members, seventeen were recorded and transcribed by hand. One interview was not recorded due to the participant's wishes while the other two were not recorded due to technical problems. Extensive notes were taken for the latter. Interviews were terminated when "theoretical saturation" was reached: The researcher realized that the additional analysis no longer contributes in providing further theoretical explanation to the emerging (grounded) theory (Cohen, Manion \& Morrison, 2007: 492). Interviews took place at a parents' choice location while the duration fluctuated between forty-five minutes and two hours.

Data analysis began at the same time with data collection and throughout the whole research these two procedures fed each other, while both of them provided constant data to shape the emerging grounded theory (Strauss \& Corbin, 2008).

Generating theoretical concepts and building a theory from empirical data (transcribed interviews) was accomplished through the three different coding processes (open, axial and selective coding). The first type of coding (open coding) involves exploring the data, identifying categories and integrating codes in a first and temporary (and not theoretically fully processed) way (Glaser, 1992: 39). Through the process of axial coding the categories derived from open coding were related and interconnected to their subcategories (Corbin \& Strauss, 1990: 13).

\section{Findings}

In this part of our paper we present the six themes that emerged from data analysis (selective coding). Interpretation of themes and excerpts from interviews, field notes and quotations follow. The latter providing evidence that the categories are well grounded in the data (Glaser \& Strauss, 1967).

\subsection{Motivation of the ASP\&G attendance}

As described in the theoretical part, according to the current institutional framework, parents and guardians do not possess substantial administrative responsibilities; in other words, they 
do not exert any influence on the general function of the schools. It should also be highlighted that based on the data deriving from the first researcher's ongoing study, the practices which are implemented by the headmasters of Greek primary schools lead to a nullification or malfunction of certain institutions in which ASP\&G participate (such as the school board or the school Assembly). However, the aforementioned does not amount to parents accepting that situation:

"I would like to have a more active participation in the administrative issues, my opinion should be equally valued with the headmistress' and the teachers' points of view, on the grounds that they do not have the knowledge to handle efficiently the matters mentioned above”. (I.P.)

The principal motivation for parents participating in ASP\&G administrative board is their desire to provide assistance to the general function of school:

"(I participate) in order to enhance the children's cultural experiences: I want them to witness and be part of something different; I want to contribute not only in the trivial issues of the school (excursions, parties), but in the essential ones as well. By collaborating with the Teachers Association and the municipality I help the school to improve”. (M.N.)

"Along with my children benefiting, the whole thing is also beneficial to me; I can further develop my mental skills by discussing different proposals and negotiating them; it is rather self-satisfying and rewarding”. (B.L.)

Many parents perceive that being close to their children and improving the quality of their education is the most significant reason for participating in the ASP\&G administrative boards:

"I put myself forward as a candidate of the ASP\&G administrative board because I want to closely supervise my children's progress and well-being at school”. (A.K.)

"I have the power to influence my child's schooling; our actions implemented thus far have a great impact on the school”. (M.D.)

Helping to solve crucial issues of the school is another significant incentive for parents ASP\&Gs board members:

“...there are so many problems in my daughter's public school; this is the reason why I want to do my best to improve the school and ensure that our children are provided with the highest quality of education”. (A.P.)

\subsection{Relations with schools}

The frequency of the ASP\&G board meetings depends on the school's issues and needs as well as the members' availability:

"Our meetings are held once a month - oftentimes more than that - depending on the needs of every term. I dedicate 10 hours out of my personal free time per month; this is the best I can do". (K.K.) 
Part of the content is shaped by the ASP\&G board members' (mainly the chair) meetings with the headmaster of the school and the municipal committee for schools. These meetings are not officially constituted, meaning their number and content are not determined by specific regulations. In recent years, however, the number of the aforementioned informal meetings seems to consistently be increasing proportionally to the problems which each school experiences.

"Our meetings with the headmaster are not official; she informs us every morning at school. We are in contact on a daily basis”. (T.A.)

The frequency of the meetings with the headmaster reflects the quality of the ASP\&G board members' bonds with the school:

"We meet with the headmaster once every trimester. In general, she does not devote much of her time to our association. Our ASP\&G administrative board consists mainly of new members, the majority of whom are First Grade pupils' parents (...). Everybody is treating us and our actions with great distrust; we are being constantly judged due to our predecessors' mishandlings.” (M.M.)

Concerning the meetings with the school board (ASP\&G administrative board, Teachers Association and a local community representative shared meetings [Law 1566/1985, Article 51, paragraph 5]), the participants of our study unanimously stated that these are constantly being postponed indefinitely because of the teachers' indifference:

"Individual teachers get us up to date over the school's issues. Teachers also update the head, who in her turn informs the ASP\&G”. (N.M.)

"The Teachers Association is not really interested, we have not organized any meetings thus far". (D.K.)

All the participants in our research seem to be concerned about the real impact parents have/ may have/ ought to have in school. A number of them, however, felt that parents are not sufficiently represented in the school; thus, the members' poor involvement in the ASP\&G activities does not - by default - justify such a discussion:

"Even if I wanted to be more active in my child's schooling, it would be impossible; most parents do not attend the meetings or events organized by the ASP\&G, they do not appear to be very interested". (B.K.)

Other participants estimate that ASP\&G administrative boards have impact on the school, which implies their capability of reshaping the school functions with a positive imprint:

"Of course I have the power to affect my child's schooling! Look at the wide array of our achievements so far! What we did triggers untold admiration!” (K.K.)

Finally, the ASP\&G board members discussed their desire for more active involvement and impact at the school level, which in some cases is expanded so that it involves pedagogical subjects: 
"I wish to be more meaningfully engaged in decision-making concerning both pedagogical and administrative issues. I want to be able to supervise the headmaster on subjects directly related to my child's education." (A.B.)

\subsection{Actions organized in favour of financially weaker students}

Parents' subscription fee, donations, social events (parties, bazaars) and other actions (lottery tickets, pupils' photo albums) comprise ASP\&G administrative boards' source of earnings. Parents' subscription fee fluctuates between two and twenty Euros. However, it seems that a high percentage of parents do not pay the subscription fee:

" $50 \%$ of the parents do not pay; we cannot do anything about that except for a written notification. Some parents do not pay because they don't care, others due to financial problems and others because they think that public schools belong to the state. They believe that paying the state exorbitant taxes has placed them in a rather unpleasant situation, which renders it impossible to afford the burden of additional expenses”. (D.M.)

School events organised for parents (meetings and workshops on various issues like "computer use", "bullying" etc.) as well as pupils' gifts and awards were ASP\&Gs' main expenses before the onset of the financial crisis. Nevertheless, in the last six years a part of these expenses are used to cover the schools' daily needs:

"Our association's money is mainly invested in miscellaneous consumables (e.g. physical education' equipment) and printing paper used by the teachers (...).” (N.D.)

Participants take a skeptical view of the aforementioned idea of contributing money for the basic services of the school (copy paper, equipment for physical education and music courses, buying computers, to name but a few). Despite these "donations" being commonly practiced, they unanimously expressed their unconditional objections:

"Parents should not fund the school, even if the school board is unable to afford its basic services' operation. Given that all responsibilities have been handed over from the state to the municipalities, the latter are obliged to handle their spending allowance in favor of education: not even 5\% of the state money has ever been invested in education up to the present moment”. (G.K.)

"Schools' basic services should be subsidized by the state and not by the parents. We were promised free education for all (...). It has never occurred to us so far but needless to say that if my children were to freeze while being at school, I would rather pay.” (G.P.)

According to our research participants, there are initiatives at every school to support the financially weaker students: food, clothes and personal hygiene items are distributed and money is raised for families in need:

"There are families at school that face serious financial difficulties who are offered free meals at the school canteen.” (D.K.) 
Additionally, ASP\&Gs contribute or cover entirely the school trip fares of financially less privileged students, buy rudimentary stationary at the beginning of the school year and pay for their school meals:

"We are able to detect the cases of parents with financial problems thanks to teachers and relatives providing us with this kind of details. The association pays for the visits of the students to doctors and collects food provisions. We do whatever we can to give them some relief. We also buy basic school items for pupils who are in need and cover the cost of school trips.” (M.B)

It should be stressed that most cases in this category seem to concern schools which have a high percentage of students whose families have been hit by the financial crisis. Despite the fact that the ASP\&G fee is less than five Euros, there are many who cannot afford it. As a result, board members ought to seek ways to support the children and their families who are hit hardest by the crisis:

"Not only the association, but the entire school as well collects food and clothes to help them (...). We also collaborate with the Municipality and the Church so as to be able to support them." (D.N.)

\subsection{Social justice and school structures}

A number of services (Reception classes, Parallel Support program and classes of Integration [of children with Special Educational Needs in common schools]) are designed to help the educational integration and success of poor families' children and pupils from different cultural backgrounds. The Compensatory education in Greece was organized in the 90s when there was a big flow of immigrants from the Eastern Europe's countries. During last few years, the structures of Compensatory Education are underfunded and, as a consequence, the aid children at risk receive is dwindling. Individuals who contributed to our research experience the life of a school whose pupils need extra care and recognize there is a gap:

"I'd like the Reception classes to have more teachers and to function as a protective circle that offers personalized help. There is no integration class because of the crisis, but I think there should be one; there are attention deficient children who need help.” (L.A.)

Positive discrimination measures, especially for people who are considered not to be part of our nation, have been heavily criticised by the extreme right, whose demagogic rhetoric seems to be gaining ground at the expense of other political groups. Nevertheless, all members of the ASP\&G boards that took part in our research were in favor of the Compensatory Education and deem that it may benefit the students:

"I think highly of the Reception classes and Parallel Support program on condition that they do not work as "parking lots" for kids, but provide children with interesting activities." (B.G.)

Certain participants in our research have expressed an opinion on the function of the Integration classes, which is close to the educational approach of a democratic public school being open to everybody (Tsiakalos, 2011): 
"I strongly support the Reception classes because they really help children. I also endorse the Integration classes; students with special educational needs should not attend special schools, because in such cases they are discriminated against and severely excluded from becoming members of their peers' social groups." (K.A.)

\subsection{Discrimination and violence in schools}

"I was at loss for words with the discrimination in our school. I felt helpless and the only thing I could do was try to understand." (N.M.)

The schools in our research have a mixed population, which means they do not only have Greek nationals, but also students from other countries and different cultural backgrounds. This fact increases the chances of racist incidents since "risk factors hinge on Otherness, in all its form" (Valentine, 2014: 90).

"Parents are discriminating against children. Mainly the teachers are the ones who have to make do with the phenomenon. Being the Chair of the ASP\&G board, I have to organize seminars about diversity, tolerance, learning difficulties and so on. I really can do no more." (K.B.)

As already mentioned above, hate preaching thrives in periods of financial crisis and more people listen to it eagerly. Consequently, prejudices multiply, as well as the incidents of discriminations and racism (Zachos, 2014):

"Yes, there are cases of discrimination in our school. Children are the worst. They don't think that they might hurt people. I have argued even with parents about discriminations and they turned against me. For example, I remember a parent once told me: "They took away our jobs, the tramps!" I try to discuss with them. I tell them they should not insult diversity and that their own child might be discriminated against one day." (L.A.)

Participants stated that discrimination and racist behaviour are not restricted only to people of different cultural backgrounds. The extreme right rhetoric of hatred is also aimed at other groups:

"Yes, there have been cases of discrimination in our school. But why are you only interested in this particular category of pupils? Pupils with disabilities also experience discrimination at school (...). In these cases we intervene using dialogue. To be honest I am not sure how to deal with these situations emerging at school and up to what extent I am entitled to intervene." (A.S.)

Incidents of racist violence that have been recorded in different schools in Greece accurately reflect how critical the situation has become (Spanou, 2013). The participants of our research are aware of the problem and are trying to contribute to its solution:

"Even the ASP\&G board members are discriminating (...) this problem should be countered from within. When children adopt racist behavior, discussing with them can improve the situation. In the cases of parents showing prejudice against others it is not the same; parents 
can become aggressive and they would not listen. They should be warned that there may be some kind of penalty." (J.K.)

3.6 Children from different cultural backgrounds and diverse performances assigned to the same classroom. Conflict or coexistence?

The members of the ASP\&G boards who took part in our research either chose to or have to send their children to schools with a varied national and ethnic population. In any case they do not belong to the category of parents who find loopholes in the law which dictates that every child must go to his / her neighborhood's school and manage to register their children in a diversity free, homogeneous school. So it seems that the board members advocate for a democratic, open-access school.

"I think highly of the coexistence of children from different cultural backgrounds (...) our school can be considered as an intercultural one (immigrants, expatriates, refugees). There are children of migrants who excel and may even carry the Greek national flag on an important official occasion. I believe it is very important to have a variety of cultures in the classroom as an element of enrichment for the pupils. The most important thing is to let children express themselves so as to exchange their individual cultural backgrounds. I say no to classes according to ethnicity, nor according to performance: we should not have schools of different "speeds". (D.P.)

"Segregated classes are unacceptable. When someone migrates they have to integrate. Here, the children of migrants are integrated and this is how it should be." (N.Z.)

There are, however, reservations deriving from the ineffective integration policies implemented by the state:

"I do not object to children from different backgrounds coexistence. However, I would like the Reception classes to function properly, helping children to adapt and integrate into the Greek culture." (M.K.)

As concerns performance-segregated classes, participants expressed the view that this is unacceptable because mixed classes help low-performance pupils to improve:

"It seems rather unrealistic to have classes of dummies and classes of geniuses. This is definitely bad for the students although it might put teachers at ease (...).” (K.P.)

"I don't want to have segregated classes according to performance, because the low-achieving pupils in mixed classes have the incentive to improve by emulation. The better performing pupils help them to improve." (X.R.)

\section{Conclusions}

In this paper we attempted to analyse the goals, incentives and profile of parents and guardians participating in ASP\&G boards, as well as the framework in which these associations take actions on issues of social justice in education. Although the literature is rich with descriptions of parental involvement in school education (Hoover-Dempsey \& Sandler, 1997; Epstein, 1995; Griffith, 2014), this study is distinctive since it aimed to 
address parental involvement under the conditions of the financial crisis and its ramifications (employment, underemployment, insecurity in employment, ineffectiveness of collective actions). Given that quite a few pupils live under the poverty threshold, schools are inadequately funded and compensatory education is malfunctioning, ASP\&G board members are obliged to face social justice issues on a daily basis. Addressing all forms of social oppression within the school setting and creating a socially just environment are core issues of social justice in education (Carlisle, Jackson \& George, 2006).

As our data suggest, ASP\&G's board members regard these as important issues. They seem to be active in taking measures towards empowering students in need; ASP\&G board members allocate their financial resources in order to facilitate the low-income pupils' schooling experience, not to mention organizing fund-raising activities in their favor. Furthermore, individuals who took part in our research showed a deep faith in equity in education: they support a democratic school, inclusive to all pupils -whatever their social class, ethnic origin, special need, sexual orientation, cognitive capabilities and skills. It must also be noted that they reject streaming and tracking. Parents actively engaged in ASP\&G boards aspire to not only improve their own children's education opportunities, but seem to also care for the entirety of school population. Having in mind that the number of individuals that participated in our research is relatively small, which means that it is not -in any caserepresentative of the total Greek parents' population, we reach the conclusion that they do not appear to compromise with current society structure nor to follow xenophobic and hatred rhetoric.

Concluding, we believe that the themes covered from our study could provide a more solid basis for further inquiry. Provided that parents and guardians are one of the three active participants in school communities, additional areas for thorough future research should include an investigation of their role in the administrative boards as well as their involvement and influence in school management. To finish with, an additional issue that would be meaningful to be addressed is related to the views and opinions of less involved parents. It is especially vital since now, a year after we completed our research, refugees' and immigrants' children who came to Greece last year should be integrated into public schools.

\section{References}

Anonymous. (2015). Exclusively in all-day program the NSRF (National Strategic Reference Framework) appointed teachers [In Greek].

Antonopoulou, K., Koutrouba, K., \& Babalis, T. (2011). Parental involvement in secondary education schools: the views of parents in Greece. Educational Studies, 37(3), 333-344. http://dx.doi.org/10.1080/03055698.2010.506332

Bogdan, R.C., \& Biklen, S. (1998). Qualitative research for education: An introduction to theory and methods, Needham Heights. MA: Allyn \& Bacon.

Carlisle, L.R. \& Jackson, B.W., \& George, A. (2006). Principles of social justice education: The social justice education in schools project. Equity \& Excellence in Education, 39(1), 55-64. http://dx.doi.org/10.1080/10665680500478809 


\section{Al Macrothink}

Journal of Studies in Education

ISSN 2162-6952

2016, Vol. 6, No. 4

Chan, B.Y.M. \&Chui, H.S. (1997). Parental participation in school councils in Victoria, Australia. International Journal of Educational Management, 11(3), 102-110. http://dx.doi.org/10.1108/09513549710163998

Charmaz, K. (2005). Grounded Theory in the 21st Century: Applications for Advancing Social Justice Studies. In Denzin, N.K. \& Lincoln, Y.S. (Eds.), Handbook of Qualitative Research, 507-535. Thousand Oaks, CA: Sage.

Charmaz, K. (2006). Constructing Grounded Theory. A Practical Guide through Qualitative Analysis. Thousand Oaks, CA: Sage.

Chikoko, V. (2008). The Role of Parent Governors in School Governance in Zimbabwe: Perceptions of School Heads, Teachers and Parent Governors. International Review of Education, 54(2), 243-263. http://dx.doi.org/10.1007/s11159-007-9080-x

Cohen, L., \& Manion, L. \& Morrison, K. (2007). Research Methods in Education. London: Routledge/ Falmer.

Coleman, M. \& Churchill, S. (1997). Challenges to Family Involvement. Childhood Education, 73(3), 144-148. http://dx.doi.org/10.1080/00094056.1997.10522672

Corbin, J., \& Strauss, A. (1990). Grounded Theory Research: Procedures, Canons, and Evaluative Criteria. Qualitative Sociology, Vol.13 (No 1), 3-21. http://dx.doi.org/10.1007/BF00988593

Creswell, J. (1998). Qualitative Inquiry and Research Design. Choosing Among Five Tradition. Thousand Oaks, CA: Sage.

Deem, R., Brehony, K., \& Hemmings, S. (1992). Social justice, social divisions and the governing of schools. In Gill, D. \& Mayor, B. \& Blair, M. (Eds.), Racism and education: Structures and strategies. London: Sage.

Epstein, J.L. (1995). School/family/community partnerships: Caring for the children we share. Phi Delta Kappan, 76(9), 701-712.

Furman, G. (2012). Social justice leadership as praxis: developing capacities through preparation programs. Educational Administration Quarterly, 48(2), 191-229. http://dx.doi.org/10.1177/0013161X11427394

Furman, G., \& Shields, C. (2005). How Can Educational Leaders Promote and Support Social Justice and Democratic Community in Schools?.In Firestone, W. and Riehl, C. (Eds.), Agenda for Research in Educational Leadership (119-137). New York: Teachers College Press.

Glaser, B.G., \& Strauss, A.L. (1967). The Discovery of Grounded Theory: Strategies for Qualitative Research. Chicago: Aldine Publishing Company.

Glaser, B.G. (1992). Basics of grounded theory analysis Emergence vs. forcing. California: Sociology Press. 
Griffith, J. (2014). The Relation of School Structure and Social Environment to Parent Involvement in Elementary Schools. The Elementary School Journal, 99(1), 53-80. http://dx.doi.org/10.1086/461916

Hellenic Parliament (2008). The Constitution of Greece.

Hoover-Dempsey, K., \& Sandler, H. (1997). Why Do Parents Become Involved in Their Children's Education? Review of Educational Research, 67(1), 3-42. http://dx.doi.org/10.3102/00346543067001003

Joubert, R., \& VanRooyen, J. (2014). Creating social justice in education through leadership training: reflections of school principals in South Africa. In Kanervio, P. \& Pulkkinen, S. \&Halttunen, L. (Eds.), Mind the gap: creating social justice through educational policy, 12-26. Jyväskylä:Jyväskylä University Printing House.

Kladakis, I. (2012). A study on parents' attitudes towards involvement in elementary school students' learning process [In Greek]. Unpublished Doctoral dissertation: National and Kapodistrian University of Athens.

Kyprianos, P. (2004). Comparative history of Greek education. Athens: Vivliorama.

Lakasas, A. (2015). "Up in the air" the all-day primary schools' operation [In Greek]. Kathimerini, August 9.

Lareau A. (1987). Social Class Differences in Family - School Relationships: The Importance of Cultural Capital. Sociology of Education, 60(2), 73-85. http://dx.doi.org/10.2307/2112583

Manesis, N. (2008). Parents' social category and their communication content with the teachers [In Greek]. In Brouzos, A. et al (Eds.), Scientific Yearbook of Northern Greece's Psychological Company, 6, 173-191. Athens: Ellinika Grammata.

Mncube, V. (2009). The perceptions of parents of their role in the democratic governance of schools in South Africa: Are they on board? South African Journal of Education, 29, 83-103. http://dx.doi.org/10.1590/S0256-01002009000100006

Mylonakou-Keke, I. (2006). Contemporary theoretical approaches in school, family and community communication [in Greek]. Athens: Atrapos.

OECD. (2011). Education Policy Advice for Greece, Strong Performers and Successful Reformers in Education. OECD Publishing. http://dx.doi.org/10.1787/9789264119581-en

Pomerantz, E.V., \& Moorman, E.A. \&Litwack. S.D. (2007). The How, Whom, and Why of Parents' Involvement in Children's Academic Lives: More Is Not Always Better. Review of Educational Research, 7(3), 373-410. http://dx.doi.org/10.3102/003465430305567

Riga, B., \& Souliara, E. (2016). Democratic Leadership and Democratic School. Unpublished (undergraduate) Thesis. Thessaloniki: Aristotle's University - Department of Primary Education. 
Shun, W. (2012). Including parents in school governance: rhetoric or reality. International Journal of Educational Management, 27(6), 667-680. Retrieved from www.emeraldinsight.com/0951-354X.htm.

Spanou, K. (Eds.) (2013). The Racist Violence Phenomenon in Greece and Its Remediation. Athens: The Greek Ombudsman. Retrieved from: http://www.synigoros.gr/resources/docs/eidikiekthesiratsistikivia.pdf.

Stern, P.N. (1980). Grounded Theory Methodology: Its Uses and Processes. Image, 12(1), 20-23. http://dx.doi.org/10.1111/j.1547-5069.1980.tb01455.x

Strauss, A., \& Corbin, J. (2008). Basics of Qualitative Research. Techniques \& Procedures for Developing Grounded Theory. Thousand Oaks, CA: Sage.

Tapper A. (2013). A Pedagogy of Social Justice Education: Social Identity Theory, Intersectionality, and Empowerment. Conflict Resolution Quarterly, 30(4), 411-445. http://dx.doi.org/10.1002/crq.21072

Theoharis, G. (2007). Social Justice Educational Leaders and Resistance: Toward a Theory of Social Justice Leadership. Educational Administration Quarterly, 43(2), 221-258. http://dx.doi.org/10.1177/0013161X06293717

Tsiakalos, G. (2011). Guide of Antiracist Education [In Greek]. Thessaloniki: Epikentro.

Valentine, D. (2014). A Critical Foundations Analysis of "The Bully" in Canada's Schools. Radical Pedagogy, 11(2), 80-103.

Young, M. (1990). Justice and the politics of difference. Princeton: Princeton University Press.

Zachos, T.D. (2007). Parents - Teachers' Relationship in Contemporary Greek School: A Case Study [In Greek]. In Kapsalis, G. \& Katsikis, A. (Eds), Proceedings of the National Conference Primary Education and its Challenges, 928-938. Ioannina. Retrieved from http://conf2007.edu.uoi.gr/Praktika/1-24.pdf.

Zachos, T.D. (2014). Racism as Agent of School Exclusion: The Case of Flampouron [In Greek]. In Zachos, T.D. (Ed.), Current Issues of Intercultural Education, 33-128. Thessaloniki: A. Stamoulis.

Zachos, T.D., \& Matziouri, A. (2015). School Leadership and Diversity: Perceptions of Educational Administrators in Greece. International Journal of Education, 7(2), 109-125. http://dx.doi.org/10.5296/ije.v7i2.7286 